\title{
INTERVIEW WITH \\ KathleEN BLEE
}

\author{
INTERVIEW CONDUCTED By \\ Stephanie Decker and Liz Legerski
}

PREPARED By

Stephanie Decker

STAR: Yesterday you talked about your work on the US racist movements and some of the emotional, ethical and methodological issues that can come up, and we also know that you've done work in gender and research in Appalachia and race weaves itself through all of those things. Can you start by describing the evolution of your interests and your work, maybe from as a student and then into your professional life, and how that evolved and came about.

Blee: It's a circuitous story. Not a linear path. I did my dissertation on a very different topic. I looked at the late $19^{\text {th }}$ early $20^{\text {th }}$ century area that's now northern Wisconsin, northeastern Minnesota and the upper peninsula of Michigan, a region which was then trying to secede as the state of "Superior." I looked at how different kinds of settlement patterns affected labor militancy in this region. I was comparing places that were settled largely by single men, who came to the U.S. to be loggers or miners, with places that were settled by families and groups and assessing what the political climate was in each place. At the time, there was a scholarly consensus that living in a family made people more conservative. But I found that while communities of single men did have more militant actions, their actions were not sustained over time. The men would go on strike, things would go downhill, and the men would leave the area rather than continue the strike. In contrast, communities settled by family units actually had more sustained militancy, even socialist organizing. 
There as a great detour in my work after that. I was doing a project on labor and militancy in the 1920s - following up on my dissertation research - and I was in the New York Public archives where I came across a brochure in favor of women's suffrage published by the $\mathrm{Ku}$ Klux Klan. It changed my research direction. I got interested in why the Klan would have supported the women's suffrage movement and I started doing some digging. I found that there had been a women's Klan in the 1920s. At the time, I thought I had discovered it, which would have been amazing because it was huge. But I later found out that historians knew about this women's Klan but had dismissed it as just an auxiliary of the 'real' Klan. But I started digging into it and found that there had been a very large and active women's Klan in the 1920s that wasn't simply an auxiliary of the men's Klan but planned actions on their own.

After I finished my study of the 1920s women's Klan, I gave many public talks about this study. I found that people were interested in the 1920s to some degree, but they really wanted to know what was happening in racists groups today. I thought that since I had a few contacts from interviewing former Klan members that I could do a contemporary version of my original study. But I hadn't really thought deeply about the difference between interviewing a 85-year-old former Klan member in a wheelchair in a nursing home and hanging out with armed 20 -year-olds. So my second book on organized racism turned out to be in a really different kind of research project.

At the time I was living in Kentucky and teaching at the University of Kentucky where I also was involved in a study of the history of Clay County, in the Appalachian part of eastern Kentucky. Clay County had been a very politically integrated and economically viable county in the $19^{\text {th }}$ century but is now one of the poorest counties in the United States. It's also one of the most persistently poor counties in the $20^{\text {th }}$ century. In this project, my colleague Dwight Billings and I looked at how a county could slide from political integration to marginality and from wealthy to poor. There's a racial part of this story as well. Today, the county is virtually all white and virtually all poor. So people think that it's always been white and it's always been poor. But just like it has 
not always been poor, it wasn't always white. In the antebellum period, Clay County was a slave state and a center of slave sales. With the abolition of slavery many free American remained in the county, but over time they were pushed out by various economic and political means and through violence and the county became white. So just like it was made poor, it was made white.

STAR: How has your work on right wing groups kind of evolved and changed over time, both concerning your emotions and how you felt about these groups that you're working with and maybe your assumptions about the people in the groups or your beliefs? I know we talked yesterday about how sometimes you come into an ethnography with one idea and then it quickly changes. How has your work with these groups changed?

Blee: Well, my assumption about what kinds of people join these groups has changed. I came into this work with the same assumptions that most people have about why people join racist groups. But I found that people I expected to be uneducated and not very informed were not necessarily like this. Often, I would interview people in racist groups who had personal libraries about the farright that, frankly, I envied. Some of them were very well educated. They had the most abhorrent views and crazy ideas, but they were educated and smart. So, my assumptions about racist activists have changed over time.

The other thing about that kind of field work is the emotions it evokes. It became harder and more problematic to do this work over time, in ways that I should have anticipated, but didn't. I started the project on the contemporary far right before the bombing of the Oklahoma City federal building. That was when the number of people in these groups was probably at its height, since many of the groups had reopened to women and some had dropped their anti-Catholic ideas and let Catholics in. Racist groups were at a high point numerically for the late $20^{\text {th }}$ century. At that time, they also were closer to mainstream politics than that they had been for awhile. Racist group members and leaders were running for electoral office, like David Duke in Louisiana. Others were trying to create what they called a 'business suit' Klan — an effort to 
have racist groups appear respectable so they could recruit from the right wing of mainstream conservative parties. These groups were above ground. You could find them fairly easily. They had offices. You could phone them up. All this meant that at the time they didn't seem particularly scary to study, especially compared to how they became later. But after the Oklahoma City bombing, there was a huge amount of federal scrutiny of these groups, because of Timothy McVeigh's connection to racist militia groups. And the people who were marginal to the groups dropped out. This had the effect of dramatically reducing the number of people in these groups because the stakes and the consequences of being a member had really gone up. So they became smaller, more underground, more suspicious of outsiders, more protective of themselves, and more convinced that they were at war with the United States. This was a big change from the 1920s Klan which was highly pro-American and nationalistic. After the Oklahoma City bombing, they began to see the government as the enemy, an enemy with which they're at war. All this made racist groups smaller, harder to deal with, and scarier to study. They became more suspicious of outsiders because the main way racist activists go to jail is through testimony of informants. So anybody who is not known to them is seen as a potential threat. This continues today.

Most of these groups no longer resemble the older groups I studied when I first started this project. Many have adopted a terrorist cell structure, where people in one cell don't even talk to people in other cells and there's not an overall organization. They just draw on the same ideas, often ideas that are circulated through the Internet, so if one cell is discovered, it doesn't lead to other cells. In this mode, their ideas are scarier, their tactics are scarier, and they're harder to study. It's made researching these groups more and more dangerous, to the point now I think it's probably almost impossible to investigate these groups directly, in an ethnographic sense, in any way that would be safe.

STAR: How would you recommend that people interested in these groups study them now, or even any groups that seem kind of extreme, or that might be kind of marginalized or that might bring kind of intense emotions to the table? 
Blee: There are two issues. One is relevant not just to racist groups, but to any groups that have a violent agenda, especially one that identifies researchers as enemies. In this case, being a researcher is not a neutral position. Right now, it's not possible to do field research with underground racist cells in a safe way. That's off the table. There are some groups that are somewhat more above ground, that can be studied, like some of the Ku Klux Klans. And racist skinheads generally do not operate as terrorist cells. These can still be studied. They're dangerous to study, but they're not impossible to study. Groups that are underground, on the other hand, are too dangerous for fieldwork study, in my opinion.

A second issue is that since many organized racist groups, especially racist cells, are monitored by the Department of Homeland Security, data gathered on these groups are susceptible to subpoena by the government. As a researcher you have no way of protecting yourself from turning over your data. You might go into these groups thinking you're not an infiltrator, but all researchers are infiltrators now in some ways, especially since passage of the Patriot Act. So there are safety issues and ethical issues. There are some extremist groups that either are not violent or who don't identify researchers as part of their enemy category. Those don't pose these issues as starkly.

People who study extremist groups always vacillate between the tug of normalizing them and the tug of being too distant. It's a general ethnographic problem. Are you too close to them emotionally, or are you too far away? That's even more of a problem if you study extremist groups. For example, in the 1920s the Klan spelled words that are spelled with a $\mathrm{C}$, instead with a $\mathrm{K}$ - as a little signal that they were in the Klan. I realized after studying them for a while that those words didn't seem misspelled to me anymore. I would see the word "Kleaners" with a K and it wouldn't even enter my brain that it was not correctly spelled. It had become part of how I thought. I didn't adopt the Klan's ideas, of course, but a problem of the ethnographic imperative to become close to those you study is that it's hard then to see what's odd about them, or what's dangerous in this case. Even when studying benign extremist groups, it's can become hard to see what's extreme about them 
if you become close to them. Ethnographers try to see the world through the eyes of those they study, but once you see the world through their eyes it might not seem unusual anymore. That can be troubling when you're studying extremist groups, especially virulently racist groups. You need to be able to see the world through their eyes, but you also need to be able to contrast their world with other worlds. And so it's an emotional dilemma. In benign extremist groups - say, religious cults - you may become friends with the people you study. And when you like people, you want to portray them as sane and interesting. But you might be too close to them to observe them fairly. Ethnographers vacillate between doing justice to our relationship with those we study and being able to evaluate them from a more distant stance.

STAR: How do you do that? What are the things that you do to ensure that? I know you mentioned sometimes stepping away from your work for a while.

Blee: Well, right now I'm doing a project on social movements in Pittsburgh, all benign groups. Some might be labeled as extremist but none are violent. And for the most part I like the people in the groups. I've studied them for a long period of time now, so I know the ups and downs of the groups and their members, even their personal problems. I feel pretty attached to these people. Now I feel a dilemma about writing about the problems in these groups. Some of this is an intellectual problem, being able to step away from the groups to see them clearly, but part of it is a problem of personal relationships. There's a difficult issue in fieldwork, where you need to maintain relationships with the people you study, but also make sure that they don't come to see you just as a friend. They need to remember that your work is observing them, not supporting them. It's an awkward balance. It can require renegotiating your relationships with the people you study in difficult ways. In ethnography there are lots of discussions about how to enter the field and how to gain access to informants, but those don't tend to be the things that ethnographers actually have a problem with. Often, ethnographers have a bigger problem exiting the field. I don't mean just walking away, but leaving people emotionally. Just like you have to negoti- 
ate a relationship when you meet people, you have to negotiate a relationship when you are no longer part of their lives in an intense way. And that can be pretty wrenching, especially when people have expectations of you and feel greatly disappointed, and you can be disappointed in yourself.

STAR: Now when you're interviewing or doing ethnographies with people who are not in extreme groups, or that you can sympathize with, have your interviewing and ethnography practices changed after interviewing people you don't sympathize with?

Blee: That's a great question! When I started, I thought I would go back to a classic feminist interviewing style, like being sympathetic to informants and so forth. And to a great extent I have, but I would say I do it in a much more cautious way than I did before. I'm much more worried now about situations in which people I interview say things they might not really want to say and about breaking a boundary of privacy that people should have, even if they are willing to violate it for my research. One thing I learned from my studies of organized racists is that people will just tell you just about anything, even things that are quite alarming. People will tell you things that are completely against their interest to say. And so I now feel a greater burden to protect people from doing that. Now I'm more likely to say, 'I want to make sure that you don't tell me things that you're going to regret later.'

STAR: Part of the skill in doing qualitative and ethnographic work is the skill of taking those individual narratives and weaving them into a historical context, or even a contemporary context, which you've done in your work. So when you're doing historical research, like your book on the Klan and some of these other things, did you find it difficult to put those individual narratives into sort of the larger context, the social context, and then the historical context? How do you go about doing that?

Blee: You have some great questions. That's a big problem with narratives. One of the things that happened in my study of contemporary racists is that, when I asked people to tell their stories (like 'how did you get to this place?') they almost all told the same 
story, stylistically. They all had the same form: some really dramatic event happened in my life and then that got me to the racial clarity that I have now. It's a common narrative structure in our society because conversion stories are very common. People narrate their lives by focusing on some dramatic pivoting event, like conversion to religion or politics or motherhood, that changed their lives. So the stories of racist women seem true because they fit my conception of how people become racist activists. And the interesting thing was that these stories did not describe how they actually joined racist groups, which I found by asking them detailed questions about the chronology of their life. I found that events that they had narrated as dramatic turning points in their lives often had not been that dramatic at the time. Only in retrospect did they seem like pivotal points in their life. Actually, most racists activists didn't become racists through a big crisis in their lives. Rather, they slid in gradually, in a very undramatic way. It's only when people tell the story later that it becomes a dramatic conversion story.

The other question is why. Why is there such a difference between what really happened and how they tell the story? I came to think it's because once they're in racist groups, they take on the dichotomous ways of thinking that these groups have. In these groups there are no shades of gray. So, how racist activists narrate their personal stories tells us how much they've absorbed that larger narrative structure from racist groups. Now they look back at their earlier lives and think - I was completely different then, and then there was a huge turning point, and here's how I am now. That's an example of individual narratives being formatted by a larger narrative structure. At first, I thought their conversion narratives had been formatted for the general public, but now I think it shows their absorption into these groups. Their absorption is total. It's not just that they have racist ideas; rather, they've reoriented their worldview in a very deep way.

STAR: You talked about people telling you things that you don't want to know when you're interviewing them. Did you feel worried about the ethical dilemmas of interviewing people who' $\mathrm{d}$ be telling you about hate crimes and having to protect their identity? 
Blee: Actually I would say that's a legal dilemma, more than an ethical dilemma. When we interview people we tell them that it's confidential, and that's just not true. We can't keep things confidential, ultimately. We claim to be able to do so, but if there's a legal challenge, we - as social scientists - have no legal standing to keep things confidential. So when people wanted to tell me about a crime, I wouldn't let them do so, even off the tape, since not only my notes and tapes, but even my memory is subject to legal subpoena. There's no protection against that. And you would be in the position of having to decide whether you wanted to refuse to turn over the material and end up in jail to protect a Nazi. So, because of this problem, I decided that the best thing was just not to ever hear that kind of stuff.

STAR: How did your appearance or your image affect your interviews? How did this affect how people saw you, or what they would be willing to tell you, or what they assume you believed?

Blee: For one thing, they all assumed I was white, which considering I set most of these things up over the phone, was interesting. It never even crossed anyone's mind that I wasn't white. Of course, you couldn't do these studies if you weren't white, because you'd put yourself in a terrible position. It wouldn't just be a matter of access. It would be dangerous.

The people in the 1920s study, those elderly women and men, not only assumed I was white, but, when I met them, they also assumed that I secretly agreed with them. So they shared racist ideas and assumed I secretly agreed. In contrast, people in contemporary racist groups never thought I agreed with them. For one thing, I started off by saying, 'I don't agree with you.' But almost nobody agrees with them, so that doesn't really stand out as much of an issue to them like it does for those who were Klan members in the 1920s who lived in communities where almost everyone did agree with them. But now most white people think racist activists are crazy. So racists expected me just to be another race traitor and it didn't surprise them that I didn't agree with them.

STAR: I know one of the important contributions of your work has 
been highlighting the role that women play in racist movements. How would you say their role has changed from the 1920s Klan to more contemporary groups?

Blee: The 1920s Klan was getting started right when the women's suffrage movement was at its height and right afterward. Historically, those movements coincided. That is one way to explain how the 1920s Women's Klan was set up. The first members of the 1920 Klan were men, but as there were more and more politically active women, and more and more very conservative, politically active women, they were an attractive pool of recruits for the Klan. Remember that one segment of the women's suffrage movement was trying to get women the right to vote because they wanted white women to outvote African American men, who had earlier gotten the right to vote. This racist wing of the women's suffrage movement was seen by Klan entrepreneurs as a great source of members. The difficult was that the women they recruited had been political activists themselves and were not interested in joining the Klan just to be under the thumbs of the guys. So they formed a separate women's Klan, affiliated with the men's Klan, but also independent of them. They had their own officers, made their own plans, and so forth. They functioned as a quasi-independent racist white supremacist movement which created a lot of conflict with the men's Klan, even street brawls. These Klans collapsed in scandal in the late 1920s. The Klan didn't exist for awhile until it resurfaced to fight the racial desegregation of schools in the South in the 1950s. That was the third Klan, which had no major women leaders.

The Klan came back again in the late 1970s and 1980s. One of the leaders of that Klan, David Duke, got an idea that the Klan could capitalize on the feminist movement by bringing women into the Klan - not because he had the slightest interest in gender equality, but because he was interested in increasing the number of members. So he started to recruit women. Since the Klans are very competitive with each other, other Klan leaders then also started recruiting women. So it snowballed. And women became part of the modern racist movement. But racist groups faced a problem, since most had been populated by guys who weren't interested in turning over the reigns of leadership to women. Thus racist groups changed 
from being all men to having increasing numbers of women, but their leadership has stayed pretty much all men.

Even the reason that racist groups recruited women ultimately turned out to be about men. After the Oklahoma City bombing and federal scrutiny, leaders of the Klans and Nazi groups got worried about infiltrators, not just about informers coming into the group, but also about people informing who are current members. So they came up with a theory that men are much more likely to become informants for the government than are women, because men are more likely either to come into the group with a preexisting criminal record or to commit a crime while they're in the group, like rob a grocery store. And either of those, a preexisting criminal record or a crime, could create a situation where the police would say, 'okay, we'll let you off if you inform on the group.' So they decided that men were more likely to be informers than women, because they're more likely to commit crimes and have a preexisting criminal record. And they saw women as safer recruits. Women were also seen as safer for another reason: when you recruit men, racist male leaders argue, he will join, but then his wife will start saying, "why are you always going to this group? I don't know what you're doing.' And she'll nag him until he drops out. But if you recruit women, they claim, not only will the women not be informers, but their husbands or boyfriends aren't going to want them just going off on their own, so they will join and the woman will be there to keep them under check. So they recruit women because, ultimately, they want men. As a consequence, today's racist groups have a lot of women in them, more than half in some, but the women are there in a provisional way; they're only supposed to be there to talk to the men and make sure they don't commit crimes. A lot of these groups have conflicts between men and women and none have women leaders. One group in the Klan was going to have a woman leader - the daughter of a Klan leader who was going to retire - but there was so much hubbub and anger from other men, that he ended up not retiring, because he couldn't turn it over to her. So the place of women in these groups has not really changed.

STAR: Looks like our time is up. Thanks for visiting with us. 